\title{
The Impact of Innovative Products in the Metallic Zinc Market Growth in Brazil
}

\author{
Nelson Roberto Furquim ${ }^{\dagger}$ \\ Universidade Presbiteriana Mackenzie
}

\begin{abstract}
International market movements have been stimulating the recent process of industrialization in Brazil, with an increasing growth in the offer and demand of higher added value products in various sectors and segments. Metallic zinc plays a significant role in the Brazilian exports and in the automotive and building industries as well. Further to the availability of new technologies, the zinc industry in Brazil has been commercializing zinc alloys, perceived as higher added value products, for several applications. This study aims at analyzing how innovation and the zinc alloys may influence the metallic commodities market development in Brazil. It was carried a nationwide survey with a non-probabilistic sample of either employees or owners of companies that use zinc and its alloys. For the answers analysis it was used the Discourse of the Collective Subject, a qualitative and quantitative methodology. Zinc alloys influence positively the metallic zinc market growth, though their high prices were considered as a restriction factor for their use.
\end{abstract}

Keywords: Innovation; Metallic zinc; Commodities; Technology; Market growth.

\section{INTRODUCTION}

Nowadays large international companies are deeply involved in activities and processes that may generate any kind of value to them, and play an important role in promoting global growth and development (MERDZANOVSKA, 2015). Phenomena such as the globalization and the internationalization of companies have been promoting a higher degree of competitiveness in different markets (KOVACS, MORAES, and OLIVEIRA, 2007). In that context innovation and application of new technologies play an important role (PRIEDE and PEREIRA, 2015), generating turbulences and dynamism, acting as vectors to increase competitiveness in various market segments (MEIRELLES, 2006; ZAHRA, SAPIENZA, and DAVIDSSON, 2006).

Considering that scenario companies intensively aim at obtaining competitive advantage, taking into account the demand conditions, their own strategies and their competitors behavior (UTTERBACK and AFUAH, 1998; AFUAH, 2009; BIELSKI, 2014; POPOVSKI and NIKOLIC, 2014).

As per the Brazilian Development, Industry and Trade Ministry, in 2011, the worldwide metallic zinc production was 13.1 million tons and the Brazilian production reached 285 thousand tons, around $2.2 \%$

Corresponding author:

† Universidade Presbiteriana Mackenzie E-mail: nelson.furquim@mackenzie.br

Received: $12 / 30 / 2015$. Revised: 03/04/2016. Accepted: 03/29/2016 Published Online: 12/01/2016.

Dol.http://dx.do1.org/10.15728/bbr.2017.14.4.3 
More than half of the worldwide zinc production is used for galvanization, a process that protects steel against corrosion, for civil construction, transportation and electrical materials among other applications. Around $14.0 \%$ is consumed for the production of zinc alloys, which significantly improve the galvanization process quality, besides imparting aesthetic benefits to the galvanized pieces, according to the International Zinc Association (IZA, 2011).

Zinc is considered the third most consumed non-ferrous metal worldwide, preceded by aluminum and copper. The average annual zinc per capita consumption in Europe is $6.0 \mathrm{~kg}$, 4.0 in the United States and $1.4 \mathrm{~kg}$ in Brazil (BRASIL, 2009).

From 2005 to 2011, commodities increased their share within the Brazilian exports moving from $29.3 \%$ to $47.8 \%$ while manufactured goods decreased from $55.1 \%$ to $36.0 \%$ (BRANCO, 2013).

The Non-Ferrous Metals Institute (ICZ, 2014) points out that the Brazilian zinc apparent consumption moved from 241.4 thousand tons in 2010 to 243.5 thousand tons in 2011 , and to 261.2 thousand tons in 2012, with annual growth rates of $0.8 \%$ and $7.3 \%$, respectively. Up to August 2013, the zinc apparent consumption in Brazil was close to 170.0 thousand tons, standing for around $65.0 \%$ of the total apparent consumption in 2012.

The Brazilian Mines and Energy Ministry points out that, historically, the growth rate of domestic zinc demand has overcome the Gross Development Product (GDP) growth rate, considering an increase in the metallic zinc production to cope with internal needs (BRASIL, 2009).

In Brazil, as far as the zinc consumption forecasts are concerned, there are some signs that in a scenario of low GPD growth rate, the domestic demand may be of 380,000 tons/ year in 2030. On the other hand, in a scenario of high GDP growth rate, the zinc demand forecast would be around 890,000 tons/year by 2030. (BRASIL, 2009).

Further to that, the importance of this study may be justified by the important role zinc plays in the Brazilian economy, considering its current production and forecasts, besides the new opportunities the Brazilian and worldwide economy growth rates may bring to a continuous demand of that metal.

From a theoretical perspective, this study allows a better comprehension of subjects related to innovation, product diversification and market growth, perceived by those who deal with metallic commodities, which are known as standardized products. The development of the study also makes it possible to understand the impact of technology in the offer of differentiated products. From an empiric point of view, the study makes it possible to evaluate the impact of technology and innovation in the offer of higher added value products in the metallic zinc segment in Brazil, besides how the offer of those products may affect the zinc market development in the country.

A worldwide study conducted by Furquim (2007), involving producers of metallic zinc and zinc based products, members of IZA, indicated that in that industry the most currently observed innovation strategy is the defensive strategy, which is commonly associated to oligopolistic markets (FREEMAN E SOETE, 1999). As far as the offer of higher added value products is concerned, the study pointed out that the level of specialization increases, and it is also observed an improvement of the involved technologies. Thus, there must be a balance between technological advances from one side and costs control from the other (FURQUIM, 2007 e 2012).

Therefore, to a better understanding of that situation in the Brazilian market, it is worth asking the following question: How may the offer of zinc alloys affect the Brazilian zinc market?

In order to answer that question, the objective of this study is to analyze how the Brazilian metallic zinc segment has been affected by the introduction of differentiated new products, 
BBR

14,4

the zinc alloys, and how innovation in this traditional segment may be considered as a tool for the development of the metallic commodities market in Brazil.

This article is organized in five sections, including this introduction. Section 2 presents the theoretical background for the study, and Section 3 brings the methodological aspects. The data presentation is brought in Section 4, and the discussion about the data and the conclusion are provided in Section 5.

\section{THEORETICAL FRAMEWORK}

\subsection{INNOVATION, TECHNOLOGY AND MARKET GROWTH}

The ability a company has to innovate is a continuous source of competitive advantage, due to the intangibility of that resource and to the fact that it is often difficult to be either copied or replaced by competitors (BRITO, BRITO, and MORGANTI, 2009). Even though innovation may occur without being necessarily related to invention (SCHUMPETER, 1943), it may present different scopes and complexity levels (GILBERT, 1994), being always related to the growth rate of the companies and of the countries (LUENGO and OBESO, 2013).

Innovation promotes the growth and the development of companies, (MULLER, VALIKANGAS, and MERLYN, 2005), being then considered as an essential resource for them (LUENGO and OBESO, 2013), and a key element to promote competitive advantage among the companies (BUCHELE, TEZA, DANDOLINI, and SOUZA, 2015). Further to that, in an ever-changing environment, companies are constantly trying to adapt through innovation in processes, people, operation, administrative practices, products and services (BAREGHEH, ROWLEY, and SAMBROOK, 2009).

Under that perspective, innovation may be defined as the use of new knowledge aiming at offering new products and services desired by customers (AFUAH, 1998), being part of an organizational process through which the companies move forward, compete and become differentiated in their markets (BAREGHEH, ROWLEY, and SAMBROOK, 2009).

The specific standard of innovation activities in a certain market sector may be explained by means of the results of different technological regimes, which may be outlined by the combination of the following four factors: technological opportunities, innovation appropriation, technological advances accumulation and knowledge base property (BRESCHI, MALERBA, and ORSENIGO, 2000).

In sectors intensive in technology high levels of radical and incremental innovation are observed whereas traditional industries, such as the metal manufacturing and metal-based products ones do not present high rates of innovation (GARRIGA, VON KROGH, and SPAETH, 2013).

As far as the market sector is still concerned, Malerba and Orsenigo (1993) point out that the nature of technological regimes impact the specific standards of innovation activities, in a way that the easy entry of innovators in a certain kind of industry is directly related to their conditions of taking advantage of the available opportunities. The ability a firm has to innovate may be strengthened as well by the knowledge-rich environment in which it is placed (GARRIGA, VON KROGH, and SPAETH, 2013).

In situations of high opportunity, there is a stronger trend of intensive use of radical strategies of research and exploitation, which may promote the growth of a company. On the other hand, when situations of low accumulation are observed, in order to promote the growth of a company, it must be strongly considered the incremental research, combined with the increasing performance of existing technologies and capabilities (MALERBA and ORSENIGO, 1993).

Nonaka and Takeuchi (2004) mention that knowledge creation is a key element for the development of innovation and that when companies innovate aiming at solving existing 
problems and trying to adjust to ever changing environments, they consider not only the information that comes from the market, but they also build up new knowledge and information.

When research and development activities are the main feature of an industry, one of the required competencies for developing and manufacturing a product is a multiple knowledge domain, which will support the establishment of technological strategies that will then lead to competitive advantage. Intense searching activities aiming at identifying and solving technical problems is a main feature of technological innovation (MICHELINO, CAMMARANO, LAMBERTI, and Caputo, 2015).

In that context, there must be point out that according to the latest edition of Innovation Survey (PINTEC), conducted by the Brazilian Institute of Geography and Statistics (IBGE), with data collected from 2009-2011, there was a decrease in the industrial sector innovation rate in Brazil during that period, lowering from $38.11 \%$ in $2006-2008$ to $35.56 \%$ (IBGE, 2011).

According to the Institute of Applied Economic Research (IPEA), that lowering happened due to some features of the Brazilian productive sector itself, the existing research infrastructure in the country, and the few incentives to leverage the firms' technological efforts and their interaction with universities and research centers (IPEA, 2013).

However, some important segments of the Brazilian industry are affected by the increase in the technological efforts, but their share in the economy decreases. That justifies why the increase in investments in Research and Development (R\&D) for the transformation industry did not lead to a better R\&D/Gross Development Product (GDP) rate in the period considered for the national survey (IPEA, 2013).

\subsection{BUSINESS DIVERSIFICATION}

The alignment between technology and market needs is essential for boosting the performance of a company, taking into account from one side the environment in which it is placed and from the other side the market strategies adopted by that specific company (DAS and VAN DE VEN, 2000). Further to that, product diversification is then considered one of the main marketing strategies for overcoming market barriers, entering new markets and increasing market shares (GABRIELSSON, GABRIELSSON, and SEPPALA 2012; GRIFFITH and RUBERA, 2014).

As a growth policy or to adopt defensive responses to the continuous competitive pressures of globalization (VARANDARAJAN, 1986), companies have been adopting product diversification as a prudent choice (ELSAS, HACKETHAL, and HOLZHAUSER, 2010), based upon their resources and capabilities, either they are tangible or intangible (QIU, 2014).

Thus, new products, resources, processes, services and organizational practices are among the main alternatives firms may adopt to compete against each other and to satisfy their customers (ETTLIE and REZA, 1992). According to those authors, a company, when searching benefits through trading new products and services, must consider that the process of innovation, to succeed, requires the simultaneous use of internally and externally integrated mechanisms.

According to Chandler (1990), changes in economies of scale and scope in different industries, countries and moments are the result of several production and distribution technologies. They affect marketplaces and their sizes, the offer of technological innovation and lead to continuous movements in the economic environment where firms are placed.

That author also mentions that the most regular incentive for a firm to diversify its activities is the potential of economy of scope in its functional units, that is, production, distribution and research. The first step towards that is the development of a complete 
BBR

14,4

production line, taking advantage of the firm's capabilities and facilities related to those three functional units. Furthermore, risk aversion and scope economies are motivations commonly taken into account for company diversification (MELHIM and SHUMWAY, 2011).

Consequently, without abandoning old product lines the company starts to produce new goods, including by-products, and that will favorably influence its production and distribution programs (PENROSE, 1995). Thus, the company may strengthen its market positioning, with a broad and varied production, minimizing vulnerabilities caused by demand fluctuations and actions of the competitors.

It must be highlighted that economies of scale and scope, when obtained through diversification processes, may lead the companies to significant financial results, besides keeping them competitive in global markets (DEL BIANCO, 2008). Under that perspective, corporate diversification strategies may lead firms to increase their profitability, to reduce risks, to reach higher growth and to expand their business life cycle (YIGIT and BEHRAM, 2013).

\subsection{NEW PRODUCTS AND MARKET DEVELOPMENT}

The resources and capabilities of a firm include its facilities, financial, human and organizational assets, which are used with the purpose of developing, producing and offering new goods and services to customers. They also allow a firm to implement strategies with the objective of improving its efficiency and effectiveness. Considering that, there are increasing opportunities to attain competitive advantage over its competitors (BARNEY, 1995; ROSTAMI, 2015).

Firms grow in a sustainable and organic way when they continuously leverage their core competences and technologies aiming at offering new products and services to the markets (Meyer, Anzani and Walsh, 2005), affecting them positively (CHAUVIN and HIRSCHEY, 1993). Those authors additionally mention that for firms, research and development expenses may be perceived as alternative ways of investing in intangible profitable assets, which lead to economies of scale and scope.

The continuously changing environment in which firms are placed will then require strategic management for adequately adapt, integrate and reconfigure their organizational resources, being them internal and external ones, besides functional competences (CIUTIENE and THATTAKATH, 2014).

Thus, innovation and new goods and services development become critical elements for business protection and growth (PINNINGTON and HASLOP, 1995), considering that the time goods and services stay in the market is vulnerable to the domestic and international competitiveness, market breakdown, demand levels and technologies availability (WHEELWRIGHT and CLARK, 1992). The fact is that firms may also remodel their business design to obtain and even increase competitive advantage, to reduce risks in opportunities and to maximize the return from innovations (SKARZINSKI and GIBSON, 2008; RODRIGUES, MACCARI and CAMPANARIO, 2011).

Considering that innovation appears as an attractive way of obtaining competitive advantage, effectively contributing to the sustainability of corporate entrepreneurship (LENGNICK-HALL, 1992), its adequate management becomes an essential tool so that firms may increasingly innovate, ensuring their long lasting operation and competitiveness (O'CONNOR, 2008).

However, there must be considered the importance of the adoption of business strategies that are specific for each different market segment, considering that new goods and services are definitely sources of competitive advantage as well, besides supporting the company's strategic direction changes. (THOMAS, 1993). Nevertheless, the way a company performs 
in terms of innovation is directly related to how it selectively allocates the available resources, which will deeply influence sales of new products and services (KLINGEBIEL and RAMMER, 2014).

From an additional perspective, innovative products and services may facilitate the internationalization of firms, allowing them to compete in specific foreign markets with greater efficiency and effectiveness (PEGAN and DE LUCA, 2015).

The establishment of worldwide stronger competition and the evolution of technologies have pushed firms in all industries to balance strategic agility and capability to innovate (DOZ and KOSONEN, 2010). Thus, on a worldwide context companies are constantly creating value through organic growth and innovation offer, in such a way that the ones that quickly adjust themselves to the ever-changing market movements will be the ones with better performances (PRAHALAD, 2005).

Innovation has been subject to studies mainly since the beginning of the twentieth century, and it is part of the economic development theory proposed by Schumpeter. That author pointed out that an innovation, in the economic sense, is complete when it is traded leading to wealth creation (SCHUMPETER, 1988.)

The capitalist model evolved, with adjustments to movements in the offer and demand of goods and services. When the use of new technologies started to be considered as a possibility for economic growth, companies began to use them more intensively for the development of innovations, which generated new products, services, processes and management models (SANTOS et al., 2011).

As of the end of the twentieth century, studies with a neoschumpeterian approach have been developed, stressing the relationship between innovation and commercial performance, under theoretical and empirical perspectives (DOSI et al., 1990). Authors of those studies highlight Schumpeter's point of view, as far as the importance of innovations for the development of the industries and the countries. They also point out that companies must constantly seek innovations as a competitive edge (SANTOS et al., 2011).

\section{METHODOLOGY}

This study is based upon the qualitative and quantitative methodology of the Discourse of the Collective Subject (DCS), which allows the identification of common sense opinions about a certain subject or a phenomenon, obtained from the answers or comments of a group of individuals. The opinion of each one of the respondents is obtained by means of open questions, which will allow the establishment of a discursive testimony (SCHOEPS et al., 2014). It favors a recovery of the thoughts, values, and beliefs individually internalized via discourses (LEFÈVRE and LEFÈVRE, 2000).

The Social Representation Theory (SRT) was adopted as a reference methodology for the current study. SRT is a kind of knowledge that is socially developed and shared, and it allows the identification of a reality that is commonly perceived by a certain social group (JODELET, 2001). SRT also deals with the product of mental activity, through which the individuals or groups of individuals reconstitute the reality they are exposed to and to which they establish a certain meaning (SÁ, 1998; JODELET, 2001).

Social representations are present in social practices, cultures and communication processes, are continuously dynamic (SÁ, 1998), and have the opinions verbalization, the attitudes and the individual and collective judgments as their basic study resources, leading to a consensus outlook on reality (JODELET, 2001).

Based upon SRT and its basic sociological assumptions, the DCS is essentially put together by analyzing each one of the collected statements about a specific subject (LEFËVRE, CRESTANA and CORNETTA, 2003). 
BBR

14,4

The DCS allows the social representations to become clearer and more focused, besides making it possible for the identification of a certain social group as the author and issuer of common sense speeches (TEIXEIRA and LEFÈVRE, 2001). It puts together as much synthesis speeches as necessary to express a specific thought or a social representation by organizing all the statements generated on the empirical social survey, which is carried out by using structured and semi-structured questionnaires (LEFËVRE, LEFÈVRE, SCANDAR, and YASSUMARO, 2004).

\subsection{STUDY SAMPLE}

For the nationwide survey, the following group of economical actors dealing with activities related to using metallic zinc and zinc-based products was defined: galvanizers, metallurgies, metallic materials producers, contractors and companies trading construction materials.

Architects and galvanizers class associations, an institute related to producers of nonferrous metals and construction materials retail stores supplied the data banks with the electronic mail addresses of potential participants of the survey. Managers, assistants and technicians of firms, architects and civil engineers were specified as the target population for this survey. It was set up a convenience, non-probabilistic sample, with spontaneous adhesion.

\subsection{PROCEDURE FOR DATA COLLECTION}

The invitations to take part in the survey were sent by electronic mail, including all the needed information and instructions for filling out the questionnaires through software QLQT On-line, version 1.0.

The survey was carried out in Brazil during January and February 2014. Four hundred and forty-five invitations were sent to potential participants, located in all geographic regions of the country.

It was used a structured questionnaire with open questions to collect the primary data. Before the roll out of the survey, the author conducted a pre-test, personally, with a group of potential respondents in São Paulo, to allow an evaluation of the understanding and to validate the questions, as far as the objectives of the survey were concerned. That procedure contributed to increase the likelihood that the terminology used in the survey might be well understood by the respondents (VAN DER STEDE; YOUNG; CHEN, 2005).

The used structured questionnaire contained six open questions related to the following major themes: innovation, technology, market growth, business diversification, launching of new products and market development, as far as the Brazilian metallic zinc market is concerned.

For each one of the proposed questions, the respondents were asked to express their perception about the impact of that specific theme on the Brazilian market.

\subsection{PROCEDURE FOR DATA PROCESSING AND ANALYSIS}

For this article, the answers to a specific question related to the impacts of the introduction of zinc alloys into the Brazilian market were analyzed.

The software Qualiquantisoft was used to process the statements, and their analysis involved selecting their key expressions (KE), identifying the central ideas (CI) of each key expression, and building up the DCS (LEFÈVRE and LEFÈVRE, 2005, p.12).

A CI is a word or a language expression used to describe, synthetically and the most accurately possible, what each analyzed statement presents as a main sense or subject (LEFÈVRE and LEFÈVRE, 2003a). Those authors also mention that KE are parts or 
sections of each one of the obtained statements, with an emphasized meaning, pointing out the essence of the speech. The combination of similar key expressions and central ideas in a “discourse synthesis" comprises the DSC (LEFÈVRE and LEFÉVRE, 2000; 2003a; 2010).

\section{DATA PRESENTATION}

This study was based upon a sample of 40 respondents, standing for $9.0 \%$ of the total of sent invitations, belonging to the five different categories of selected actors, dealing with activities related to using metallic zinc and zinc based materials in Brazil. From the respondents, $80.0 \%$ were male; $47.0 \%$ had the position of managers in companies trading construction materials and $97.0 \%$ had finished at least elementary school or technical courses.

The analysis of the answers to the following question "If you had to tell someone how the offer of zinc alloys may affect the Brazilian zinc market, what would you mention?" led to four categories of CI, as shown on Table 1.

Table 1. Distribution of the frequencies of the CI categories identified in answers of different actors dealing with activities related to using zinc and zinc based materials to the following question "If you had to tell someone how the zinc alloys offer may affect the Brazilian zinc market, what would you mention?" - Brazil, 2014.

\begin{tabular}{llll}
\hline Category & & Answers & $\%$ \\
\hline A & Positive opinions about the zinc alloys offer in the Brazilian market & 16 & 32.7 \\
B & Negative opinions about the zinc alloys offer in the Brazilian market & 12 & 24.5 \\
C & Need of more knowledge about the use of zinc alloys & 10 & 20.4 \\
D & Without any opinion about the offer of zinc alloys in the Brazilian market & 11 & 22.4 \\
& Total & 49 & 100.0 \\
\hline
\end{tabular}

Source: the author

The proposed question had the purpose of identifying if the respondents perceived benefits and disadvantages with the offer of zinc alloys in the Brazilian market. From the obtained answers, $32.7 \%$ of them indicated positive opinions about the offer of zinc alloys in the Brazilian market. They mentioned the possibility of a wide range of applications for the alloys, besides bringing aesthetic benefits, protection against corrosion, better quality of the finished products in which they are used, leading to differentiated products in the domestic market, with a high level of competitiveness if compared to imported finished products.

Around $25.0 \%$ of the answers presented negative opinions about the offer of zinc alloys in the Brazilian market, mainly due to their high prices, which makes their use unfeasible. Respondents also mentioned that the use of zinc alloys implies additional production costs, without any guarantee of financial return. There were also indications that the final consumers do not pay any attention to the quality and benefits brought by the use of zinc alloys, and that they are used only in selected finished products.

It must be pointed out as well that $20.4 \%$ of the answers indicated the need of a better knowledge about the use of zinc alloys, including the search for use extension, the creation of new product lines, or even the improvement of finished products currently available in the market. 


\subsection{DISCUSSION ABOUT THE DATA}

The respondents mentioned that the zinc alloys launched in the Brazilian market are perceived as new products, even though they are not considered very different from the ones already existing in the market. They are not perceived as brand new innovation, but as improvements of the products already available in the market. Thus, the zinc alloys are not considered as radical innovation, taking into account that they are obtained from existing knowledge and products (AFUAH, 1998).

As the zinc alloys have been made available in the Brazilian market, there has been noticed an alignment with the offer of similar products in the international market, reinforcing the positive impression of differentiated products in the domestic market (GILBERT, 1994). That approach also aligns with what is pointed out by Nonaka and Takeuchi (2004), when they mention that by launching new products in the market, the companies internalize knowledge from the outside boosting the environment where they are placed.

Thus, there is a reasonable prospect of continuance in the demand for zinc alloys, based upon the ongoing expectations of the users for new and innovative products, associated with requirements for products with a higher degree of quality and a broader scope of applications (BRASIL, 2009).

Those opportunities for growth in the zinc alloys consumption in Brazil are aligned with the favorable performance of several sectors, which are intensive in applications for those products. Two sectors are particularly significant in that context: the automotive industry which had the best historical results in 2013, with the production of 3.7 million vehicles, an increase of about 10.0\% compared to 2012 (AGÊNCIA BRASIL, 2014), and the building and construction industry (EXAME.COM, 2013).

The country industrialization process, together with an efficient industry development, worldwide competitive makes it possible the competitiveness with imported products (MEYER, ANZANI and WALSH, 2005; PEGAN and DE LUCA, 2015).

Taking advantage of those opportunities may lead to an increased market dynamism (MALERBA and ORSENIGO, 1993), besides promoting an environment of innovative activities for the zinc alloys producers as well, involving the use of new technologies, technological advances accumulation and intellectual property (BRESCHI, MALERBA and ORSENIGO, 2000), which positively impacts the market growth (MULLER, VALIKANGAS and MERLYN, 2005). Further to that, the offer of differentiated products leads to changes in the size of the domestic zinc and zinc-based products markets, aligned with what mentions Chandler (1990).

The corporate environment becomes more complex and accelerated as time goes by, which leads the successful firms to constantly review their business models within their market segments, and redefine them whenever it is necessary(DOZ and KOSONEN, 2010; CIUTIENE and THATTAKATH, 2014).

The respondents also pointed out that the zinc alloys offer meets several users' requirements, in different market sectors and segments, and that using those new products is among the main alternatives the companies may take into account to become more competitive and to respond to their consumers' needs and expectations (ETTLIE and REZA, 1992). Besides allowing firms diversification, innovation becomes a significant element of competitiveness standards, and promotes increases in revenues and profits (AFUAH, 1998; BUCHELE, TEZA, DADOLINI and SOUZA, 2015).

From that perspective, zinc alloys users stressed that those products, by being differentiated, allow new applications and business expansion (MEYER, ANZANI and WALSH, 2005), which may benefit the companies in obtaining competitive advantages (BARNEY, 1995). Firms that quickly adapt themselves to ever changing markets offer 
their customers added value products and integrated solutions, remodeling the interaction between suppliers and consumers, and generating new sources of revenues (SKARZINSKI and GIBSON, 2008; RODRIGUES, MACCARI and CAMPANARIO, 2011; KLINGEBIEL and RAMMER, 2014).

Considering that the zinc alloys offer indicates a connection between innovation and competitive advantage, the respondents observed that with those products there is a market evolution, involving various aspects of the consumption chain (UTTERBACK and AFUAH, 1998). On the other hand, among the answers related to the negative opinions about the offer of zinc alloys in the Brazilian market there were noticed some comments referring to the fact that by being more expensive, those products might increase production costs, which might generate restrictions to their use as well.

Countries with lack of technologies, credit and opportunities usually are associated with old and poor industries (CHANDLER, 1990). On the other hand, the commercial relationships among the countries and the flow of knowledge and personnel become the basis for the markets dynamics (THOMAS, 1993; MEYER, ANZANI and WALSH, 2005).

It must be also noticed that the alignment of the Brazilian market with the worldwide trends in terms of higher add value products availability allows the domestic companies, users of zinc alloys, to offer their finished products on equal terms when compared to those internationally offered. Therefore, it is a way of facing the movement of international companies that intend to act in the Brazilian market (URBAN and HAUSER, 1993; O ESTADO DE SÃO PAULO, 2013).

Despite the positive opinions about the offer of zinc alloys in the Brazilian market be around $33.0 \%$, more than $20.0 \%$ of the answers indicates a need of more knowledge concerning the use of those products. It is also significant the amount of answers (around $22.0 \%$ ) related to those respondents who do not have any opinion concerning the offer of zinc alloys in the Brazilian market. In both cases, there are opportunities to revert the situation pointed out by the survey, through institutional information about the use of the alloys, disseminated by producing companies and class associations, which could eventually lead to an increase in the percentage of positive opinions. Additionally, the Brazilian consumer market has grown lately (BRASIL, 2009) and the domestic consumption will push the economic activity of the country (ICZ, 2014).

\subsection{FINAL CONSIDERATIONS}

The objective of this study was to analyze how the Brazilian metallic zinc segment has been affected by the introduction of differentiated new products, the zinc alloys, and how innovation in this traditional segment may be considered as a tool for the development of the metallic commodities market in Brazil.

The study was based upon the qualitative and quantitative methodology of the Discourse of the Collective Subject (DCS), and for that, there was performed a nationwide survey involving galvanizers, metallurgies, metallic materials producers, contractors and companies trading construction materials, economical actors dealing with activities related to using metallic zinc and zinc-based products.

From a theoretical perspective, development of the study allowed a better understanding of the impact of technology in the offer of differentiated products, besides a comprehension of subjects related to innovation, product diversification and market growth. From an empiric point of view, the study made it possible to evaluate the impact of technology and innovation in the offer of higher added value products in the metallic zinc segment in Brazil, and how they may affect the development of a specific market.

The results of the survey indicated that the offer of metallic zinc based new products, with higher benefit, directly impacts the Brazilian zinc market as a whole, making it aligned 
BBR

14,4

with the offer of similar products in the international market. In order to promote the flow of knowledge, a country must be open to interact with other nations, to receive multinational companies and to offer its products in a global chain (GABRIELSSON, GABRIELSSON, and SEPPALA, 2012; GRIFFITH and RUBERA, 2014).

The zinc alloys, being innovative products in the traditional market of metallic commodities become tools for market development and growth, promoting an intensive dynamism and stronger competitiveness among the companies that use them. From that perspective, the new technologies play an important role through which the companies seek gains of competitive advantage over their competitors. It is vital to understand that economies only grows with the widening of the interactions among its actors, favored by the availability of technology, qualified personnel and entrepreneurship (LUENGO and OBESO, 2013; MERDZANOVSKA, 2015). With that scenario, the links among the actors become stronger, which allows them to take part in broader networks, to accumulate knowledge and to reach higher levels of complexity (BAREGHEH, ROWLEY and SAMBROOK, 2009).

Considering that zinc alloys are basically for industrial purposes, alternatives to be considered in order to increase the knowledge on the benefits and advantages of using them refer to an institutional task force among zinc alloy producers and end user companies, in order to offer training and technical lectures, besides courses at the main universities. Another contribution may come up from technical articles in specific journals.

This study is subject to some limitations such as the use of the internet for the survey and the non-probabilistic sample of respondents. Thus, in order to obtain a more detailed approach of the positions identified in this study, future researches might promote a better understanding of the contributions zinc alloys may bring to the development of the Brazilin metallic zinc market, and how they could generate more competitiveness to the producers and end users.

\section{REFERENCES}

AFUAH, A. Innovation management: strategies, implementation and profits. New York: Oxford University Press, 1998.

AFUAH, A. Strategic Innovation: new game strategies for competitive advantage. New York: Routledge, 2009.

AGÊNCIA BRASIL. Indústria automobilística fecha 2013 com crescimento de 9,9\% na produção. Recovered from: $\quad<$ http://memoria.ebc.com.br/agenciabrasil/noticia/2014-01-07/industria-automobilistica-fecha2013-com-crescimento-de-99-na-producao>. Access on: 11 Nov. 2014.

BAREGHEH, A., ROWLEY, J.; SAMBROOK, S. Towards a multidisciplinary definition of innovation. Management Decision,v.47, n. 8, p. 1323-1339, 2009.

BARNEY, J. Looking inside for competitive advantage. Academy of Management Executive, v.9, n. 4, p. 49$61,1995$.

BIELSKI, I. Evolution of managers'opinions on usability of different resources for developing competitive advantages. Recovered from: $<$ http://web.a.ebscohost.com/ehost/pdfviewer/ pdfviewer?vid=27\&sid=11ffe317-5347-4dac-97af-ef3524f875ec\%40sessionmgr4005\&hid=4214 $>$. Accesson: 10 dez. 2014.

BRANCO, R. S.RaulPrebisch e o desenvolvimento econômico brasileiro recente liderado por commodities. Revista Cadernos de Estudos Sociais e Políticos, v. 2, n. 3, p. 95-129, 2013.

BRASIL. Ministério das Minas e Energia. Produto 39, Cadeia do Zinco, Relatório Técnico 65, Perfil do Zinco. Recovered from: <http://www.mme.gov.br/sgm/...brasil/P39_RT65_Perfil_do_Zinco.pdf >. Access on: 20 jan. 2015.

BRASIL. Ministério do Desenvolvimento, Indústria e Comércio. Zinco. Recovered from: <http://www.mdic. gov.br/sitio/interna/interna.php?area=2\&menu=4184\&refr=3257>. Access on: 18 Jul. 2015.

BRESCHI, S.; MALERBA, F.; ORSENIGO, L. Technological regimes and schumpeterian patterns of innovation. The Economical Journal, v. 110, n. 463, p. 388-410, 2000. 
BRITO, E. P. Z.; BRITO, L. A. L.; MORGANTI, F. Inovação e o desempenho empresarial: lucro ou crescimento? RAE- eletrônica, v. 8, n. 1, p. 1-24, 2009.

BUCHELE, G. T.; TEZA, P.; DANDOLINI, G. A.; SOUZA, J. A. Souza. Análise dos artigos qualitativos empíricos sobre métodos, técnicas e ferramentas para inovação. RAM, Rev. Adm. Mackenzie, v. 16, n. 3, p. 136-170, 2015.

CHANDLER, A. D. Scale and scope: the dynamics of industrial capitalism. Cambridge, Mass: Harvard University Press, 1990.

Chauvin, K. W.; HIRSCHEY, M. Advertising, R\&D expenditures and the Market value of the firm. Financial Management, v. 22, n. 4, p. 128-140, 1993.

CIUTIENNE, R.; THATTAKATH, E. W. Influence of dynamic capabilities in creating disruptive innovation. Economics and Business, v. 26, p. 15-21, 2014.

DAS, S.; VAN DE VEN, A. H. Competing with new product technologies: a process model of strategy. Management Science, v. 46, n. 10, p. 1300-1316, 2000.

DEL BIANCO, V. S. Análise de estratégias de diversificação: um estudo de caso em uma indústria de cosméticos. Recovered from: <http://www.abepro.org.br/.../enegep2008_TN_STP_075_533_11705.pdf > Access on: 19 out. 2015.

DOSI, G.; PAVITT, K.; SOETE, L. The economics of technical change and international trade. London: Harvester Wheastsheaf, 1990.

DOZ, Y. L.; KOSONEN, M. Embedding strategic agility. Long Range Planning, v. 43, n. 2-3, p. 370-382, 2010.

ELSAS, R.; HACKETHAL, A.; HOLZHAUSER, M. The anatomy of bank diversification. Journal of Banking and Finance, v. 34, n. 6, p. 1274-1287, 2010.

ETTLIE, J. E.; REZA, E. M.Organizational integration and process innovation. Academyof Management Journal, v. 35, n. 10, p. 795-827, 1992.

EXAME.COM. Indústria de construção civil deve crescer 2,8\% em 2014. Recovered from: <http:// exame.abril.com.br/economia/noticias/industria-brasileira-de-construcao-civil-deve-crescer-2-8-em2014?page $=2>$. Access on: 09 Mar. 2015.

FREEMAN, C.; SOETE, L. The economics of industrial innovation. 3rd. ed., Cambridge: The MIT Press, 1999.

FURQUIM, N. R. Dinâmica competitiva e estratégias no segmento do zinco. Dissertação de mestrado. Universidade Presbiteriana Mackenzie, São Paulo, Brasil, 2007.

FURQUIM, N. R. Padrão de concorrência na indústria de commodities: um estudo internacional envolvendo empresas produtoras de zinco. Revista ADM.MADE, v. 16, n. 3, p. 21-36, 2012.

GABRIELSSON, P.; GABRIELSSON, M.; SEPPALA, T. Marketing strategies for foreign expansion of companies originating in small and open economies: the consequences of strategic fit and performance. Journal of International Marketing, v. 20, n. 2, p. 25-48, 2012.

GARRIGA, H., VON KROGH, G.; SPAETH, S. How constraints and knowledge impact open innovation. Strategic Management Journal, v. 34, p. 1134-1144, 2013.

GILBERT, J. T. Choosing an innovation strategy: theory and practice. Business Horizons, v. 37, n. 6, p. 1622, 1994.

GRIFFITH, D. A.; RUBERA, G.A Cross-Cultural Investigation of New Product Strategies for Technological and Design Innovations. Journal of International Marketing, v. 22, n. 1, p. 5-20, 2014.

INSTITUTO BRASILEIRO DE GEOGRAFIA E ESTATÍSTICA (IBGE). PINTEC Pesquisa de Inovação 2011.Recoveredfrom: $<\mathrm{http}$ //www.pintec.ibge.gov.br/index.php?option=com_content\&view $=$ category $\&$ layout=blog\&id=27\&Itemid=43>. Access on: 17 Mar. 2016.

INSTITUTO DE METAIS NÃO FERROSOS (ICZ). Estatística dos metais. Recovered from: < http://www. icz.org.br/estatisticas-dos-metais-2013.php>. Access on: 27 set. 2015.

INSTITUTO DE PESQUISA ECONÔMICA APLICADA (IPEA). Nota Técnica no. 15. Análise dos dados da PINTEC 2011.Recovered from: <http://www.ipea.gov.br/agencia/images/stories/PDFs/nota tecnica/131206_notatecnicadiset15.pdf $>$. Access on: 17 mar. 2016.

INTERNATIONAL ZINC ASSOCIATION (IZA). Zinc uses. Recovered from: <http://www.zinc.org/basics/ zinc_uses>. Access on: 24 jun. 2015.

JODELET, D. As representações sociais. Rio de Janeiro: UERJ, 2001.

KLINGEBIEL, R.; RAMMER, C. Resource allocation strategy for innovation portfolio management. Strategic Management Journal, v. 35, n. 2, p. 246-268, 2014.

KOVACS, E. P.; MORAES, W. F. A.; OLIVEIRA, B. R. B. Redefinindo conceitos: um ensaio teórico sobre os conceitos-chave das teorias de internacionalização. Revista de Gestão USP, v. 14, p. 17-29, 2007. 
BBR

14,4

LEFÈVRE, F.; LEFÈVRE, A. M. C. Os novos instrumentos no contexto da pesquisa qualitativa. In: LEFÈVRE, F.; LEFĖVRE, A. M. C.; TEIXIERA, J. J. V., org. O discurso do sujeito coletivo: uma nova abordagem metodológica em pesquisa qualitativa. Caxias do Sul: EDUCS; 2000.

LEFÉVRE, A. M. C.; CRESTANA, M. F.; CORNETTA, V. K.A utilização da metodologia do discurso do sujeito coletivo na avaliação qualitativa dos cursos de especialização "Capacitação e Desenvolvimento de Recursos Humanos em Saúde - CADRHU”, São Paulo - 2002. Saúde e Sociedade, v. 12, n. 2, p. 68-75, 2003.

LEFÈVRE, F.; LEFÈVRE, A. M. C. Discurso do sujeito coletivo: um novo enfoque em pesquisa qualitativa (desdobramentos). Caxias do Sul: EDUCS, 2003a.

LEFÉVRE, F.; LEFĖVRE, A. M. C.; SACANDAR, S. A. S.; YASSUMARO, S.Representações sociais sobre relações entre vasos de plantas e o vetor da dengue. Revista de Saúde Pública, v. 38, n. 3, p. 405-414, 2004.

LEFÉVRE, F.; LEFÈVRE, A. M. C. Depoimentos e discursos: uma proposta de análise em pesquisa social. Brasília (DF): Liber Livro, 2005, p. 12.

LEFÈVRE, F.; LEFÈVRE, A. M. C. Pesquisa de representação social: um enfoque qualiquantitativo - a metodologia do Discurso do Sujeito Coletivo. Brasília: LivroEditora, 2010.

LENGNICK-HALL, C. A. Innovation and competitive advantage: what we know and what we need to learn. Journal of Management, v.8, n. 2, p. 399-429, 1992.

LUENGO, M. J.; OBESO, M. El efecto de la triple hélice en los resultados de innovación. Revista de Administração de Empresas, v. 53, n. 4, p. 388-399, 2013.

MALERBA, F.; ORSENIGO,C. Technologicalregimes and firm behavior. Industrial and Corporate Change, v. 2, n. 1, p. 45-71, 1993.

MEIRELLES, D. S.O conceito de serviço. Rev. Econ. Polit., v. 26, n. 1, p. 119-136, 2006.

MELHIM, A.; SHUMWAY, C. R. Enterprise diversification in the US dairy: impact of risk preferences on scale and scope economies. Applied Economics, v. 43, n. 26, p. 3849-3862, 2011.

MERDZANOVSKA, M. The technology strategy of transnational companies. Recovered from: <http:// web.a.ebscohost.com/ehost/pdfviewer/pdfviewer?vid=8\&sid=11ffe 317-5347-4dac-97af-ef3524f875ec\% 40sessionmgr4005\&hid=4214>. Access on: 24 abr. 2015.

MEYER, M. H.; ANZANI, M.; WALSH, G. Innovation and enterprise growth: how IBM develops next generation product lines. Research Technology Management, v. 48, n. 4, p. 34-44, 2005.

MICHELINO, F.; CAMMARANO, A.; LAMBERTI, E.; CAPUTO, M. Caputo. Knowledge domains, technological strategies and open innovation. Journal of Technology Management and Innovation, v. 10, n. 2, p. 50-78, 2015.

MULLER, A.; VALIKANGAS, L; MERLYN P. Metrics for innovation: guideline for developing a customized suite for innovation. Strategy and leadership, v. 33, n. 1, p. 37-45, 2005.

NONAKA, I.; TAKEUCHI, H. Criação de conhecimento na empresa. Rio de Janeiro: Elsevier, 2004.

O ESTADO DE SÃO PAULO. Brasil atrai mais áreas estrangeiras. Recovered from: <http://economia. estadao.com.br/noticias/geral,brasil-atrai-mais-aereas-estrangeiras-imp-,1049661>. Access on: 27 set. 2015.

O’CONNOR, G. C.; LEIFER, R.; PAULSON, A. S.; PETERS, L. S. Peters. Grabbing lightning: building a capability for breakthrough innovation. San Francisco: John Wiley \& Sons, 2008.

PEGAN, G.; DE LUCA, P. Innovation and internationalization: evidences from the Italian furniture industry. International Journal of Management Cases, v. 17, n. 4, p. 188-207, 2015.

PENROSE, E. The theory of the growth of the firm. Oxford: Oxford University Press, 1995.

PINNINGTON, A.; HALSLOP, D. Team leader autonomy in new product development. Management Decision, v. 33, n. 9, p. 5-11, 1995.

POPOVSKI, V.; NIKOLIC, S. Nikolic. The significance of the organizational knowledge for acquiring competitive advantage on the telecommunication market in the Republic of Macedonia. Economic Development, v. 1-2, p. 31-47, 2014.

PRAHALAD, C. K.Learning to lead. Vikalpa, v.30, n. 2, p. 1-9, 2005.

PRIEDE, J.; PEREIRA, E. T. Innovation as a key factor in the international competitiveness of the European Union. Procedia - Social and Behavioral Sciences, v. 207, p. 680 - 689, 2015.

QIU, T. Product diversification and market value of large international firms: a macroenvironmental perspective. Journal of International Marketing, v. 22, n. 4, p. 86-107, 2014.

RODRIGUES, L. C.; MACCARI, E. A.; CAMPANARIO, M. A. Expanding the open innovation concept: the case of Totvs S/A. Journal of Information Systems and Technology Management, v. 7, n. 3, p. 737-754, 2011. 
ROSTAMI, N. A. Examining the relationship between marketing capability and innovation. International Journal of Management, Accounting and Economics, v. 2, n. 1, p. 64-72, 2015.

SÁ, C. P. A construção do objeto de pesquisa em representações sociais. Rio de Janeiro: EdUERJ, 1998.

Santos, A. B. A.; Fazion, C. B., Meroe, G. P. S. Inovação: um estudo sobre a evolução do conceito de Schumpeter. Caderno de Administração da Faculdade de Administração da FEA PUC/SP, v. 6, n. 1, 2011.

SCHOEPS, D.; LEFÈVRE, F.; SILVA, Z. P.; NOVAES, H. M. D.; RASPANTINI, P. R.; ALMEIDA, M. F. Social representations of obstetricians and neonatologists about fetal and early neonatal death certificate in the city of São Paulo. Revista Brasileira de Epidemiologia, v. 17, n. 1, p. 105-118, 2014.

SCHUMPETER, J. A. Capitalism, socialism and democracy. London: George Allen \&Unwin, 1943.

SCHUMPETER, J. A. A teoria do desenvolvimento econômico. São Paulo: Nova Cultural, 1988.

SKARZINSKI, P.; GIBSON, R. Innovation to the Core. Boston (MA): HBS Press, 2008.

TEIXEIRA, J. J. V.; LEFÉVRE, F. A. A prescrição de medicamentos sob a ótica do paciente idoso. Revista de Saúde Pública, v. 35, n. 2, p. 207-213, 2001.

THOMAS, R. J. New Product Development: managing and forecasting for strategic success. New York: John Wiley \& Sons, 1993.

UTTERBACK, J. M.; AFUAH, A. The dynamic "diamond": a technological innovation perspective. Economics of Innovation and New Technology, v. 62, n. 3, p. 183-199, 1998.

VAN DER STEDE, W. A.; YOUNG, S. M.; CHEN, C.X. Assessing the quality of evidence in empirical management accounting research: the case of survey studies. Accounting, Organizations and Society, v. 30, p. 655-684, 2005.

VARADARAJAN, P. R. Product diversity and firm performance: an empirical investigation. Journal of Marketing, v. 50, p. 43-57, 1986.

WHEELWRIGHT, S. C.; CLARK, K. B. Revolutionizing product development: quantum leaps in speed, efficiency, and quality. New York: The Free Press, 1992.

YIGIT, I.; BELHAM, N. K. The relationship between diversification strategy and organizational performance in developed and emerging economy contexts: evidence from Turkey and Netherlands. Eurasian Business Review, v. 3, n. 2, p. 121-136, 2013.

ZAHRA, S. A.; SAPIENZA, H. J.; DAVIDSSON, P. Entrepreneurship and dynamic capabilities; a review, model and research agenda. Journal of Management Studies, v. 43, n. 4, p. 917-955, 2006. 